Exploring the Influences of Internal Branding on Employees' Brand Promise Delivery: Implications for Strengthening the Customer-Brand Relationships 


\title{
Exploring the Influences of Internal Branding on Employees' Brand Promise Delivery: Implications for Strengthening the Customer-Brand Relationships
}

\author{
Khanyapuss Punjaisri \\ Nottingham Trent University, UK \\ Alan M. Wilson \\ University of Strathclyde, UK \\ Heiner Evanschitzky \\ University of Strathclyde, UK
}

\begin{abstract}
Internal branding is increasingly seen as a doctrine to ensure employees' delivery of the brand promise by shaping employees’ brand attitudes and behaviours. However, few studies, if any, were conducted into understanding the internal branding process from the viewpoint of employees who are the end receivers. Therefore, this study aims at exploring employees' perceptions towards the internal branding process. It identifies the relevant mechanisms and describes how internal branding affected service employees. The challenges of its success are uncovered and discussed. Finally, managerial implications and future research directions are provided.
\end{abstract}

Keywords: Internal branding, customer-interface employees, brand, internal relationships, customer-brand relationships 
For service organisations, brand is considered as a relationship builder (e.g. Blackett and Harrison, 2001; Ryder, 2004; Webster, 2000). It creates an intimate bond with customers based on its value proposition or a brand promise (Barnes, 2003; Muniz and O’Guinn, 2001). The promise needs to be fulfilled at each service encounter to secure the longevity of customer-brand relationships (Berry, Conant, \& Parasuraman, 1991; McQuiston, 2003; Zeithaml, Berry, \& Parasuraman, 1993).

The branding and service marketing literatures have recognised employees’ influences on customers during service encounters (e.g. de Chernatony and Segal-Horn, 2001; DenbyJones, 1995). Recent studies (see Herington, Johnson, \& Scott, 2006) of the relationship marketing literature view the firm-employee relationship as a prerequisite to the customerfirm relationships and, thus, the organisation's superior success. It is argued that the way employees are taken care of implies how they will take care of an organisation's customers. Therefore, it can be logically extended that the perceptions that employees have towards the brand could affect the customers' perceptions. This being the case encourages an organisation to create employees' shared understanding of what and how the promise needs to be fulfilled so that customers experience the brand as expected. However, while an organisation relies on employees to deliver on its brand promise so as to strengthen customers' trust in the relationship, there is a concern over the employees' heterogeneous quality. As a result, internal branding has recently been introduced to the branding literature to ensure that employees are attitudinally and behaviourally ready to represent the brand and deliver on its promise accordingly. However, due to its emergent phase, there has been a dearth of research conducted into the process required to encourage brand-supporting behaviours (WittekeKothe, 2001). As observed by de Chernatony and McDonald (2002), there is a dearth of studies that depict the need to create employees' understanding of the brand promise although they are central to the development of customer-brand relationships. This could explain why 
Boone (2000) remarked that there was a disconnection between external and internal branding initiatives, resulting in a mismatch between the promised and the enacted brand values. Moreover, whilst authors have advocated treating employees as internal customers, there is a lack of studies that took account of the employees' perspective. The existing insights have generally stemmed from research with management and brand practitioners. Therefore, this paper aims at unearthing the perspective of employees, who deliver the brand values to customers, in relation to the internal branding process. Specifically, this paper has two broad objectives:

1. To uncover the perceptions of customer-interface employees towards internal branding in relation to the promise delivery.

2. To provide a theoretical framework for better understanding of an internal branding process.

\section{Literature Review}

\section{The Link between Internal and External Relationships}

Despite a number of different typologies developed (Doyle, 1995; Gummesson, 1999; Morgan and Hunt, 1994), both practitioners (e.g. Carlzon, 1987; Freiberg and Freiberg, 1998; Harris, 1996; Rosenbluth and McFerrin Peters, 1992, 1998) and scholars (e.g. Schlesinger and Heskett, 1991; Heskett et al, 1994) concur that building relationships with employees is a prerequisite to customer-firm relationships. There is also an agreement that a good employeefirm relationship positively impacts the performance and profitability of the firm. In fact, employees are recognised as a critical part of a chain of relationships network (Anderson and Weitz, 1989; Gummesson, 1999; Kandampully and Duddy, 1999). For service organisations, employees even constitute the entire chain of relationship between the firms and customers. 


\section{Service Employees as Keys to Customer-Brand Relationships}

Another aspect of relationship marketing focuses on the importance of trust. Although there are different perspectives in the role that trust and commitment play in a relationship model, authors agree that they are the key components in relationship marketing (e.g. Mohr and Nevin, 1990; Morgan and Hunt, 1994) and trust precedes customers' relationship commitment (e.g. Beatty et al, 1996; Berry, 1995; Doney, Cannon, \& Mullen, 1998). Several authors have argued for the critical role of customer-interface employees in directly fostering strong long-term customer-brand relationships (e.g. Crosby and Stephens, 1987; Doney and Cannon, 1997; Sirdeshmukh and Sablo, 2002). An empirical study within the French commercial bank sector by Paulin, Perrier, \& Ferguson (1997) supports the importance of employees who are apparent during service encounters on customer trust and, accordingly, a customer-brand relationship.

Authors (e.g. Kroeber-Riel, 1984; Wemberg, 1993; Wohlfeil and Whelan, 2006) argue that emotional involvement of customers underpins the customer-brand relationships. Emotional connections may be difficult to establish due to service intangibility which hinders customers’ value perceptions. However, several authors (e.g. Fournier, 1998; O’Loughlin, Szmigin, \& Turnbull, 2004) have suggested the concept of brand as personality to facilitate the transmission of brand values to external constituencies. As such, a well-established brand personality creates an emotional tie with customers, thereby increasing preference and patronage as well as develops customers' trust and loyalty (Biel, 1992; Siguaw, Matilla, \& Austin, 1999). Jacobs (2003) argue that employees who constantly interact with customers are the representative of the brand personalities. As such, the critical role of employees in building a customer-brand relationship is further highlighted. 


\section{Service Employees as a Challenge in the Delivery of the Brand Promise}

Swan and Nolan (1985) argue that trust is built over time and dependent on a result of experience with the partner. According to O’Malley (1991), customers come to a brand because they expect to experience the brand values that are proposed via a promise so that the possession of the particular brand reflects their personal values. Therefore, the promise needs to be fulfilled when they are in contact with a brand. For service brands, the delivery of the brand promise relies heavily on employees who are at the interface between the brand and customers. Schultz and Schultz (2000) posit that customer-interface employees have to behave in ways that are aligned with the brand values encapsulated in a form of a brand promise. However, along the 'service journey', customers tend to encounter different service providers. Any differences in employees' behaviours throughout the course of service transactions raise a problem in controlling brand experience and performance perceived by customers (Clemes, Mollenkopf, \& Burn, 2000), thereby undermining an organisation’s attempt to establish relationships with customers. Failure to keep the promise over time adversely affects the development of customers' trust and commitment which are the key elements of a relationship.

\section{Internal Branding and Internal Marketing}

Drake, Gulman, \& Roberts (2005) argue that internal branding is instrumental in influencing employees to deliver the brand promise on customer's brand expectation and is created through the practice of internal marketing. The success practice of internal branding engenders a shared brand understanding among employees which should create committed workforce who deliver on the brand promise. Previously, internal branding was promoted as the responsibility of marketing which was primarily about communicating (e.g. Bergstrom, Blumenthal, \& Crothers, 2002). Recently, Machtiger (2004) regarded the sole reliance on 
internal communications as one pitfall in internal branding and suggested a broader integrative framework across marketing, management, and human resource (HR) disciplines. $\underline{\text { Internal Communication }}$

Internal branding initiatives need supports from communication strategy taking account of both external and internal communication practices (Hallam, 2003). Internal Communications should be the first point of focus in an internal branding programme (Zucker, 2002), aiming to secure people's commitment and encourage behavioural change to support the brand such as customer-orientation (George and Grönroos, 1991). Terry (2003) has recently observed that there is a trend that merits marketing knowledge to successfully engage employees with the brand in terms of internal branding activities. He argues that because marketers know the brand and understand people's motivation, needs, desires, and weaknesses, they are capable of communicating the brand to an internal audience and shape people’s perceptions. Hence, marketing people add value in the field of internal communications and help the company to improve performance from the inside out.

\section{$\underline{\text { Human Resource Practices }}$}

Recent studies (e.g. Hankinson, 2004; Punjaisri and Alan, 2007) suggest the coordination of the efforts of marketers and human resource managers to underpin any internal branding programmes. After reviewing the existing research of HR in relation to internal marketing, three common practices, namely recruiting, training, and compensating, are found. First, an organisation should attempt to select the prospects whose values are in congruence with its brand and the organisation per se (de Chernatony, Drury, \& Segal-Horn, 2003). Training, then, enhances employee performance and their understanding about living the brand promise. Finally, to maintain brand standards, an organisation should remunerate and reward employees accordingly (Hoffman and Mehra, 1999) to enhance their motivation and 
commitment. Hence, HR people should work in coordination with marketing people to ensure that the coherent brand message is embedded in all internal branding activities.

\section{Research Method}

Being at an infancy stage, the internal branding concept lacks the consistent theoretical framework and measurements for internal branding. Therefore, this study is of the exploratory nature, following the qualitative approach to emphasise discovery over confirmation (Wells, 1993). The qualitative case study strategy was adopted to help establish a deep understanding of a specific phenomenon and develop ideas for further study instead of concluding it (Yin, 1994).

\begin{tabular}{|c|c|c|c|c|}
\hline \multicolumn{5}{|c|}{ Table 1 Profile of Informants from Six Hotels } \\
\hline Job Position & Hotel & Department & Sex & Age \\
\hline Housekeeping supervisor (R1) & \multirow{5}{*}{$\mathrm{D}$} & Housekeeping & $f$ & 42 \\
\hline Banquet Manager (R2) & & $F \& B$ & $\mathrm{~m}$ & 38 \\
\hline Communication centre officer (R3) & & F/O & $\mathrm{f}$ & 28 \\
\hline Sales reception co-ordinator (R4) & & $\mathrm{F} / \mathrm{O}$ & $\mathrm{f}$ & 29 \\
\hline Reservation supervisor (R5) & & F/O & $\mathrm{f}$ & 38 \\
\hline Housekeeping supervisor (R6) & \multirow{5}{*}{$\mathrm{H}$} & Housekeeping & $\mathrm{f}$ & 41 \\
\hline F\&B supervisor (R7) & & $F \& B$ & $\mathrm{~m}$ & 30 \\
\hline F\&B officer (R8) & & $F \& B$ & $\mathrm{~m}$ & 32 \\
\hline F\&B server (R9) & & $F \& B$ & $\mathrm{~m}$ & 35 \\
\hline Guest history officer (R10) & & Residence & $\mathrm{f}$ & 27 \\
\hline $\begin{array}{l}\text { Guest contact assistant manager at café } \\
\text { (R11) }\end{array}$ & \multirow{5}{*}{ M } & $F \& B$ & $\mathrm{f}$ & 34 \\
\hline Assistant F\&B personnel (R12) & & $F \& B$ & $\mathrm{f}$ & 30 \\
\hline $\begin{array}{l}\text { Guest contact supervisor at restuarant } \\
\text { (R13) }\end{array}$ & & $F \& B$ & $\mathrm{f}$ & 26 \\
\hline Sales executive (R14) & & Services & $\mathrm{f}$ & 34 \\
\hline Bell boy (R15) & & Services & $\mathrm{m}$ & 31 \\
\hline Guest service officer (R16) & \multirow{5}{*}{$\mathrm{O}$} & $\mathrm{F} / \mathrm{O}$ & $\mathrm{m}$ & 24 \\
\hline Room attendant (R17) & & Housekeeping & $\mathrm{m}$ & 28 \\
\hline Waiter (R18) & & $F \& B$ & $\mathrm{~m}$ & 23 \\
\hline Concierge officer (R19) & & F/O & $\mathrm{f}$ & 25 \\
\hline Porter (R20) & & F/O & $\mathrm{m}$ & 36 \\
\hline Room maid (R21) & \multirow{5}{*}{$\mathrm{P}$} & Housekeeping & $\mathrm{f}$ & 22 \\
\hline Guest relations officer (R22) & & $\mathrm{F} / \mathrm{O}$ & $\mathrm{f}$ & 25 \\
\hline F/O supervisor (R23) & & $\mathrm{F} / \mathrm{O}$ & $\mathrm{m}$ & 30 \\
\hline Hostess (R24) & & $F \& B$ & $\mathrm{f}$ & 26 \\
\hline Server (R25) & & $F \& B$ & $\mathrm{f}$ & 23 \\
\hline Café captain (R26) & \multirow{5}{*}{ S } & F\&B & $\mathrm{f}$ & 32 \\
\hline Chinese restaurant captain (R27) & & $F \& B$ & $\mathrm{f}$ & 38 \\
\hline Busboy (R28) & & $F \& B$ & $\mathrm{~m}$ & 23 \\
\hline Guest relations officer (R29) & & $\mathrm{F} / \mathrm{O}$ & $\mathrm{f}$ & 25 \\
\hline Business centre officer (R30) & & $\mathrm{F} / \mathrm{O}$ & $\mathrm{f}$ & 23 \\
\hline
\end{tabular}

The unit of study in this research is the hotel industry in Thailand, represented by 6 hotel brands in different major tourism cities assuring that they provide international-level services 
to both national and international customers. The selection of hotels was based on their quality standards signified by starts, 4- and 5- star hotels were selected as it was felt that they would make efforts to protect their brand and reputation. A member of senior management of each hotel was contacted to gain access and an insight into key informants of this research. It was suggested interviews be taken with employees from Front office (F/O), Food \& Beverage (F\&B), and Housekeeping (HK) departments. Table 1 displays the final list of customerinterface employees who took part in in-depth interviews. A total of 30 customer-interface employees were conducted to generate data for the study. Each interview lasted between one hour and one hour and thirty minutes.

Given the exploratory nature of this research, a broad list of topics under study was outlined in a semi-structured manner to ensure the flexibility to probe any issues that arose during the interview. They were asked to think about the perceived relevant mechanisms of internal branding and to describe how internal branding affects them and their brand promise delivery. Thereafter, they were invited to discuss any perceived challenges of the internal branding process. To facilitate an open and honest dialogue, each interview took place in their business office. All interviews were tape-recorded and transcribed for interpretation. All 30 interview transcripts were content analysed. The similar themes and statements were categorised together and were reduced to more broad global themes based on the research questions. The relationships between these global themes are portrayed in figure 1.

\section{Findings}

Analysis of interview transcripts revealed three broad themes: internal branding mechanisms, internal branding outcomes, and possible moderating factors. Both internal communication and training programmes are perceived as key internal branding mechanisms. The effects of these mechanisms on the expected outcomes were moderated by personal variables and situational variables. 


\section{Key Mechanisms of Internal Branding}

Two principal mechanisms that were mentioned by all informants included internal communication and training programmes. Internal communication was considered as a key to 'give' them 'an idea about the brand' (R30). A variety of training courses were regarded as coaching and educating them about the precise attitudes and behaviours necessary to deliver on the brand promise. That is, 'training is educating how to enact the espoused brand values as proposed by the brand promise' (R1).

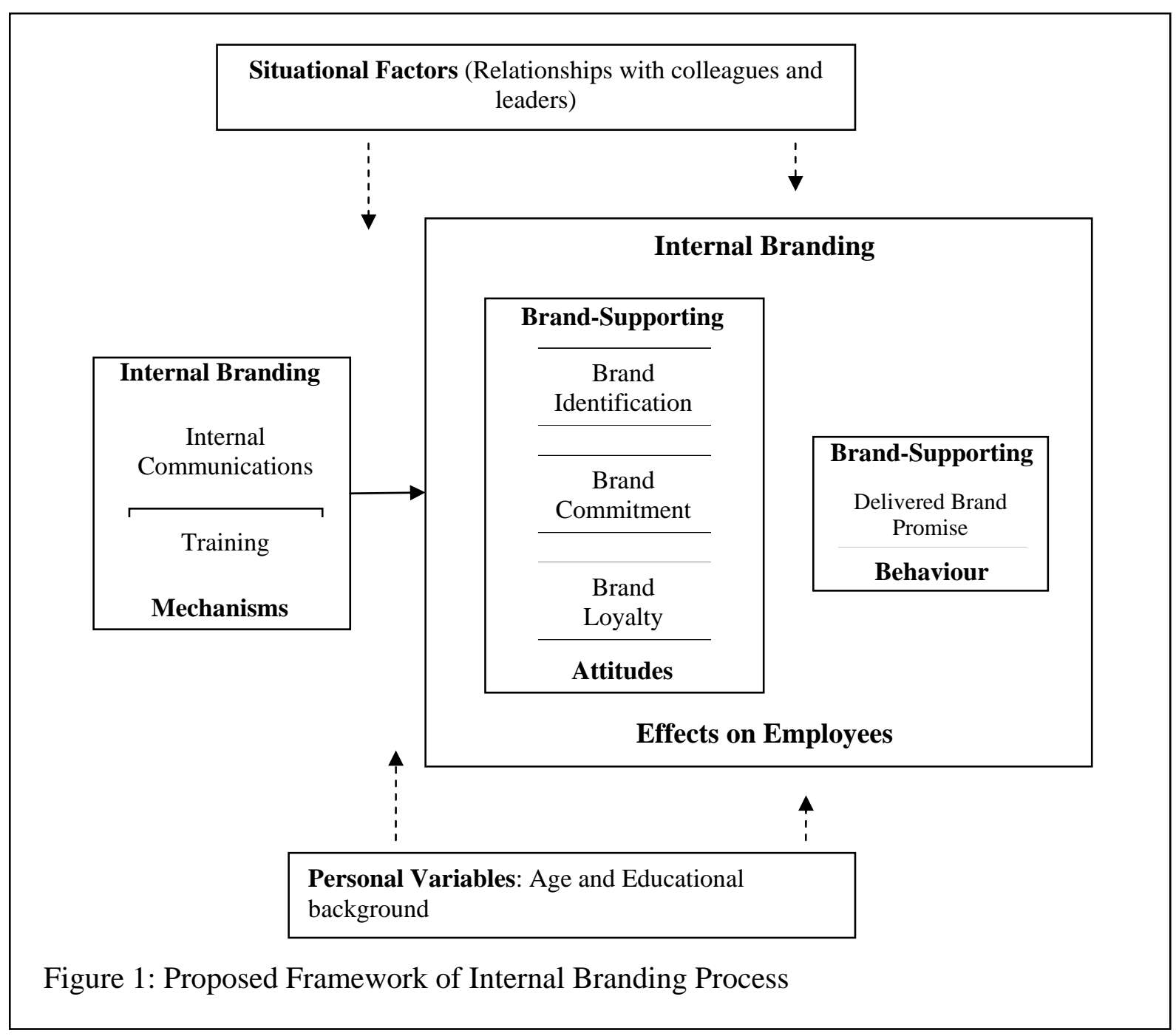

\section{Internal Communication Techniques \& Tools}

The analysis of the findings discovered the practice of two-way communications in every participating hotel. Most informants referred to a technique such as 'speak-out box', 'direct 
line' and 'free-talk session' as a vehicle to 'send a message or suggestion to management' (R23). Also, they discussed the importance of diagonal communications in terms of informal communication across functional units during the promise delivery: 'When issues occur, I know exactly which department and who to go to so that the delivery of the brand promise continues smoothly' (R3).

A number of internal branding tools were identified and can be categorised into three broad categories: a) mass methods such as newsletters (10/31 employees), and notice boards (17/30); b) written memos such as logbooks (15/30); and c) face-to-face communication including daily briefing (30/30) and group meetings (28/30). Face-to-face communication was preferred by the majority of informants because it provides an opportunity to 'express our opinions, ask for answers to clarify our uncertainty right away' (R25), making it 'the clearest method' (R29) whereas mass methods reached both external and internal audiences so as to ensure the coherent brand message. Both mass methods and written memos were found to be used as a back-up so that employees could 'go back and read it again to remind [them] about what to do' (R8). Altogether, internal communication provided them essential information and knowledge, thereby enabling them to effectively follow the brand standards and deliver on the brand promise.

\section{HR Practices: Training Programmes}

Training is the only HR practice that was perceived as relevant to their understanding of the brand during the internal branding process. The importance of coordinating internal communication with training was highlighted throughout each interview. The majority of informants (26/30) discussed the indispensability of both mechanisms in a successful internal branding programme because 'one should be trained to understand how the communicated brand message can be delivered during service encounters' (R7). 


\section{Internal Branding's Outcomes}

All informants accepted that they needed internal branding to be in place because 'it helped understand what the brand and its promise is to ensure that we [employees] deliver the brand as expected by customers' (R19). In particular, the findings suggested that internal branding affected employees both attitudinally and behaviourally.

\section{Attitudinal Effects}

Brand Identification: Internal branding was considered important because it enhanced their sense of pride and belonging to the brand (brand identification). It was considered essential to enhance their skills and capabilities to meet customer expectations. The confidence allowed them to fulfil the brand promise which 'positively influences my [employee] pride in Hotel O' (R16). Furthermore, because they were kept informed about what and how the brand was doing, their sense of belonging increases as one (R15) said: 'when customer satisfaction scored lower than expectation, there was disappointment across all employees'.

Brand Commitment: Several expressions such as 'love', 'like', and 'enjoy' were used to reflect their emotional attachment with their hotel. Their attachment was further extended to other hotel properties under the same brand. For example, 'I love working with [M]. I worked with it in the US and am still working for it now in Thailand' (Assistant F\&B personnel, Hotel M) and 'I moved from O in Bangkok to work for O in Chiang Mai because I moved my house here. This is all because I love working with O' (Room attendant, Hotel O). It was also apparent that the participating employees were committed to make their brand better and more reputed: 'I believe that most of us, if not all, are willing to deliver on the brand promise because we want to see our brand successful and our guests satisfied' (Sales reception coordinator, Hotel D). This is all because ‘we are kept reinforced about brand values' (R27).

Brand Loyalty: Although the hotel industry is characterised by high-turnover of staff, the majority (17/30) of informants expressed their intention to stay with the hotel because 
internal branding enhanced their knowledge, skills and capabilities. 'It's been giving me training to enhance my capabilities. I don't see any reasons to leave’ (R13).

\section{$\underline{\text { Behavioural Effect }}$}

The findings discovered that brand-supporting attitudes partially drove employees' brandsupporting behaviours. Some informants discussed link between their positive attitudes and brand-supporting behaviours. When employees identified themselves with the brand, it was more likely that they delivered on the brand promise: 'I'll do my best in fulfilling the brand promise because I want to succeed and I want the brand to succeed' (R21). Similarly, committed and loyal employees exerted an effort to follow the brand standards guiding their delivery of the brand promise. For example, 'I love working here and I intend to work for a long while so I am thriving to perform up to the brand standards to assure my delivery of the brand promise' (R20). Despite the influences of the attitudes on their behaviours, internal branding remained pivotal to give clear guidelines on how to deliver on the brand promise during service encounters. 'I think that both communications and training are essential. I believe that I can deliver on the brand promise because of them' (R26).

\section{Challenges in the Internal Branding Process}

Situational factors pertaining to the work environment were found to challenge the success of internal branding. The findings resonated with past studies that highlighted the importance of internal relationships. Personal variables including age and educational background were mentioned by the informants as potential deterring factors.

\section{$\underline{\text { Relationships with Colleagues and Leaders }}$}

All informants referred to the relationships with colleagues and their leaders as influential on their attitudes and performance in delivering the brand promise. When they felt 'comfortable with colleagues' (R5) and that their colleagues were 'supportive' (R22), they felt 'part of the hotel brand' (R2), which increased their commitment and intention to stay. This is because 
'we succeed as a team so I don't want to let my colleagues down so I do my best to be in the team' (R24). Positive relationships among workers also enhanced their performance in delivering the brand promise: 'I need support from my colleagues to ensure a smooth delivery of the brand promise' (R7).

The relationships that employees have with their leaders were found to impact the success of an internal branding process. Most informants expressed their positive perceptions toward the relationship with their leaders. They further revealed that part of their commitment and intention to stay was due to their relationships with managers. For example, one informant (R8) said: 'our managers are friendly and helpful ... makes me wish to do the best in my role'. Therefore, 'the comfortable relationships with colleagues and my managers make me feel that I am part of this brand and continue to work with this hotel' (R5).

\section{Personal Variables}

Employees' intention to stay was also tied to their age. The informants whose age over 30 years old expressed their intention to stay more than those who were less than 30 years old. Younger employees expressed their ambition to advance in the career, whereby they might leave for other hotels of a different brand. Educational background was found to have the same influence on employees' loyalty. Most of the well-educated informants admitted that they might leave the hotel for career opportunities in other hotels despite the good work environment. One informant's expression could summarise the effect of both age and education on brand loyalty: With this age and degree, I might leave this job to work for another brand that appears more prestigious. I'll miss my colleagues but I need advancement in my career' (Business relations officer, Hotel S). However, the findings did not explicitly reveal the effects of these personal variables on other attitudes and behaviours. Implicitly, it seemed that employees who intended to stay with the brand believed that they were 
committed to deliver on the brand promise more than those who did not show their loyalty to the brand as in previous sections.

\section{Discussion}

Based on the finings, a conceptual framework is proposed in Figure 1. Internal communications and training programmes were identified as the two most important and relevant mechanisms in the internal branding process. It is advisable that an organisation should attempt to adopt two-way communications and encourage diagonal communications/informal communications as suggested by Sonenberg (1991) to enhance their delivery of the brand promise. While the studies of internal marketing which were conducted with management and consultants suggested that recruiting and rewarding as the key elements of HR practice, this study which attempted to unearth the perceptions of employees toward internal branding emphasised training as the key tool of HR in the internal branding process. Both internal communications and training need to be coherently orchestrated to disseminate consistent brand messages across employees.

This research reflected the belief of various authors (e.g. Davies, 2004; de Chernatony, 2001) about internal branding influencing employees’ attitudes and behaviours. It further revealed that internal branding enabled an organisation to influence employees' brand identification in terms of their sense of belonging, brand commitment or emotional attachment, and brand loyalty expressed as their intention to stay. Because commitment and emotional aspects are treated as important relationship elements within the marketing and non-marketing literatures (Herington, Scott, \& Johnson, 2005), this research posited that internal branding could strengthen the relationships the employees have with the brand. Regarding the delivery of the brand promise, internal branding should provide employees with a clear understanding of what the brand and its promise is to optimise their potential for delivering the brand promise. While previous studies did not suggest the link among these themes, this research discovered 
that employees' brand attitudes as influenced by internal branding had an impact on their delivery of the brand promise; this suggested an opportunity for future research to explore any possible mediational effect of these brand attitudes.

While Mudie (2000) criticised internal marketing for lacking focus on internal relationships, this research recognised that employees' positive perceptions towards their colleagues and leaders could enhance the effect that internal branding had on their attitudes towards brand and behaviours in delivering the brand promise. However, the effects of personal variables such as age and education should also be taken into account. Well-educated and young employees, despite positive attitudes towards the brand and their work environment, may still intend to leave the brand for career advancement.

\section{Managerial Implications}

Results of this study highlight the importance of coordinating training programmes and internal communications in any internal branding programme. An integrative internal branding process allows management to positively influence their employees’ identification with, commitment, and loyalty to the brand, which implicates the strength of the internal relationships (Herington, Scott, \& Johnson, 2005). With the positive attitudes, employees may expend their efforts to deliver on the brand promise in order to satisfy customers and, thus, effectively develop a long-term relationship with customer. Also, management could exploit internal branding for shaping employees' brand behaviours. By employing both training and internal communications, management can induce a shared understanding among employees about the brand promise and how to deliver it, thereby ensuring that customers experience the brand as proposed.

Another interesting implication of this research is the challenging factors in an internal branding process. They could, on one hand, affect the strength of internal relationships as they might either hinder or enhance the effect of internal branding on employees' brand 
attitudes. On the other, both situational factors and personal variables could also deter the effect of internal branding on the employees' delivery of the brand promise, thereby affecting the establishment of customer-brand relationships. This is because a service brand relies heavily on employees to develop the relationships with customers. When they cannot fulfil the brand promise, customers’ trust in brand could be jeopardised.

\section{Limitations and Future Research}

Although this study reveals some interesting findings, a few limitations should be taken into account. First, the study focused solely on customer-interface employees. However, service brands require the involvement of all employees across organisations. Therefore, there is an opportunity for future research to explore the perceptions of back-of-the house employees. In addition, this study focused solely on the hotel industry. Further generalisation of these findings should be made after studies conducted with other industries in the service sector because some of which may possess a different degree of customer-employee interaction.

However, a qualitative interview aims at understanding a particular phenomenon, rather than uncovering inter-relationships between key constructs based on a large sample (McCracken, 1988). Therefore, while the findings of this study emerge from data derived from a small number of informants, future survey-based studies could offer empirical evidence of the link between internal branding and employees’ brand attitudes, and between internal branding and employees' behaviours in delivering the brand promise. In addition, this research has revealed possible moderating factors and mediators in the internal branding process. Thus, it is advised that future research should attempt to empirically assess these mediational and moderating effects.

\section{References}

Anderson, E. and Weitz, B. (1989). Determinants of Continuity in Conventional Industrial Channel Dyads. Marketing Science, 8(4), 310-317. 
Barnes, J. G. (2003). Establishing Meaningful Customer Relationships: Why Some Companies and Brands Mean More to their Customers. Managing Service Quality,13(3), 178-186.

Beatty, S. E., Mayer, M., Coleman, J. E., Reynolds, K. E. and Lee, J. (1996). Customer-Sales Associate Retail Relationships. Journal of Retailing, 72(3), 223-247.

Bergstrom, A., Blumenthal, D. and Crothers, S. (2002) 'Why Internal Branding Matters: The Case of Saab'. Corporate Reputaion Review, 5(2/3), 133-142.

Berry, L. L. (1995). Relationship Marketing of Service-Growing Interest, Emerging Perspectives. Journal of the Academy of Marketing Science, 23(4), 236-245.

Berry, L. L., Conant, J. S. and Parasuraman, A. (1991). A Gramework for Conducting a Service Marketing Audit. Journal of the Academy of Marketing Science, 19, 255-268.

Biel, A. L. (1992). How Brand Image Drives Brand Equity. Journal of Advertising Research, 32(6), RC6-RC12.

Blackett, T. and Harrison, T. (2001). Brand Medicine: Use and Future Potential of Branding in Pharmaceutical Markets. International Journal of Medical Marketing,2(1), 33-49.

Boone, M. (2000). The Importance of Internal Branding. Sales and Marketing Management, 9, 36-38.

Carlzon, J. (1987). Moments of Truth. New York, NY: Ballinger Publishing.

Clemes, M. Mollenkopf, D. and Burn, D. (2000). An Investigation of Marketing Problems Across Service Typologies. The Journal of Services Marketing, 14(7), 573-594.

Crosby, L. A. and Stephens, N. J. (1987). Effects of Relationship Marketing on Satisfaction, Retention, and Prices in the Life Insurance Industry. Journal of Market Research, 24, 404411.

De Chernatony, L. and McDonald, M. (2002) Creating Powerful Brands in Consumer, Service and Industrial Markets (2nd ed). London: Butterworth-Heinemann.

de Chernatony, L. and Segal-Horn, S, (2001). Building on Services Characteristics to Develop 
Successful Services Brands. Journal of Marketing Management, 17(7/8), 645-669.

de Chernatony, L., Drury, S. and Horn, S. (2003). Building a Services Brand: Stages, People, and Orientations. The Service Industries Journal, 23(3), 1-21.

Denby-Jones, S. (1995). Mind the Gap. The Banker, 145(833), 66-67.

Doney, P. M. and Cannon, J. P. (1997). An Examination of the Nature of Trust in Buyer-Seller Relationships. Journal of Marketing, 61(2), 35-51.

Doney, P. M., Cannon, J. P., and Mullen, M. R. (1998). Understanding the Influence of National Cultuure on the Development of Trust. The Academy of Management Review, 23(3), 601-620.

Doyle, P. (1995). Marketing in the New Millennium. European Journal of Marketing, 29(13), 23-41.

Drake, S. M., Gulman, M. J. and Roberts, S. M. (2005). Light Their Fire, Chicago: Dearborn. Fournier, S. (1998). Consumers and Their Brands: Developing Relationship Theory in Consumer Research. Journal of Consumer Research, 24(4), 343-373.

Freiberg, K. and Freiberg, J. (1998). Nuts! Southwest Airlines' Crazy Recipe for Buusiness and Personal Success.New York, NY: Broadway Books.

George, W. R. and Grönroos, C. (1991). Developing Customer Conscious Employees at Every Level - Internal Marketing. In Congram, C. A. and Friedman, M. L. (Eds.). Handbook of Marketing for the Service Industries (pp. 85-100), New York, NY: AMACOM.

Gummesson, E. (1999). Total Relationship Marketing. Oxford: Butterworth Heinemann. Hallam, R. (2003). Delivering the Brand Promise at Washington Manual. SCM, 7(4), 18-21. Hankinson, P. (2004). The Internal Brand in Leading UK Charities. Journal of Product \& Brand Management, 13(2), 84-93.

Harris, J. (1996). Getting Employees to Fall in Love With Your Company. New York, NY: American Management Association. 
Haynes, P. and Fryer, G. (2000). Human Resources, Service Quality and Performance: A Case study. International Journal of Contemporary Hospitality Management, 12(4), 240-248.

Herington, C., Johnson, D., and Scott, L. W. (2005). Focus Group Exploration of FirmEmployee Relationship Strength. Qualitative Market Research, 8(3), 256-276.

Herington, C., Johnson, L. W., and Scott, D. (2006). Internal Relationships: Linking Practitioner Literature and Relationship Marketing Theory. European Business Review, 18(5), 364-381.

Heskett, J. L. et al (1994). Putting the Service-Profit Chain to Work. Harvard Business Review, 72(2), 164-172

Hoffman, J. M. and Mehra, S. (1999). Operationalizing Productivity Improvement Programs through Total Quality Management. The International Journal of Quality \& Reliability Management, 16(1), 72.

Jacobs, R. (2003). Turn Employees into Brand Ambassador. ABA Bank Marketing, 35(3), 2326.

Kandampully, J. and Duddy, R. (1999). Competitive Advantage through Anticipation, Innovation and Relationships. Management Decision, 37(1), 51-56.

Kroeber-Riel, W. (1984). Zentrale Probleme auf Gestigten Märkten. Marketing - Zeitschrift fur Forschunng und Praxis, 6(3), 210-214.

Machtiger, B. (2004). Beware Pitfalls that Kill Branding Efforts. Marketing News, 38(4), 21.

McCracken, G. (1988) The Long Interview. Newbury Park, CA: Sage.

McQuiston, D. H. (2004). Successful Branding of a Commodity Product: The Case of RAEX LASER Steel. Industrial Marketing Management, 33(4), 345.

Mohr, J. and Nevin, J. R. (1990). Communication Strategies in Marketing Channels: A Theoretical Perspective. Journal of Marketing, 54(4), 36-51.

Morgan, R. M. and Hunt, S. D. (1994). The Commitment-Trust Theory of Relationship 
Marketing. Journal of Marketing, 58(3), 20-34.

Mudie, P. M. (2000). Internal Marketing: A Step Too Far. In Varey, R. J. and Lewis, B. R. (Eds.), Internal Marketing: Directions for Management (pp. 254-280). London: Routledge.

Muniz, A. M. and O’Guinn, T. (2001). Brand Community. Journal of Consumer Research, 27, 412-432.

O’Loughlin, D., Szmigin, I. and Turnbull, P. (2004). Branding and Relationships: Customer and Supplier Perspectives. Journal of Financial Services Marketing, 8(3), 218-230.

O’Malley, D. (1991). Brand Means Business. Accountancy, 107, 107-108.

Paulin, M., Perrien, J. and Ferguson, R. J. (1997). Relational Contract Norms and the Effectiveness of Commercial Banking. International Journal of Service Industry Management, 8(5), 432-452.

Punjaisri, K. and Alan, W. (2007). The Role of Internal Branding in the Delivery of Employee Brand Behaviour. Journal of Brand Management, 15(1), 57-70.

Rosenbluth, H. and McFerrin Peters, D. (1992). The Customer Comes Second: and Other Secrets of Exceptional Service. New York, NY: Quill.

Rosenbluth, H. and McFerrin Peters, D. (1998). Good Company: Caring as Fiercely as You Compete. Reading, MA: Addison-Wesley.

Ryder, I. (2004). Anthropology and the Brand. Journal of Brand Management, 11, 346-356.

Schlesinger, L. A. and Heskett, J. L. (1991). Enfranchisement of Service Workers. California Management Review, 33, 83-100.

Schultz, D. E. and Schultz, H. (2002 ). IMC, The Next Generation: Five Steps for Delivering Value and Measuring Returns Using Marketing Communication, CA: McGraw-Hill Siguaw, J. A., Matilla, A. and Austin, J. R. (1999). The Brand-Personality Scale. Cornell Hotel and Restaurant Administration Quarterly, 40(3), 48-55. 
Sirdeshmukh, D. and Sablo, B. (2002). Consumer Trust, Value and Loyalty in Relational Exchanges. Journal of Marketing, 66(1), 15-37.

Sonenberg, F. K. (1991) 'Internal Communication: Turning Talk into Action'. The Journal of Business Strategy, (November/December), 52-55.

Swan, J. E. and Nolan, J. J. (1985). Gaining Customer Trust: A Conceptual Guide for the Salesperson. Journal of Personal Selling and Sales Management, 5(2), 39-48.

Terry, N. (2003). Marketers Merit a Greater Role in Internal Activity. Marketing (UK), 8/28/2003, 18.

Webster, F. E. (2000). Understanding the Relationships among Brands, Consumers, and Resellers. Journal of Academy of Marketing Science, 28(1), 17-24.

Wells, W. (1993). Discover-oriented consumer research. Journal of Consumer Research, 19(4), 489-504.

Wemberg, P. (1993). Cross Cultural Aspects of Emotional Benefit Strategies. European Advances in Consumer Research, 1, 84-86.

Witteke-Kothe, C. (2001). Interne Markenführung-Verankerung der Markenidentität im Mitarbeiterverhalten. Wiesbaden: Deutxher Universitätsverlag GmbH.

Wohlfeil, M. and Whelan, S. (2005). Event-Marketing as Innovative Marketing Communications: Reviewing the German Experience. Journal of Customer Behavior, 4(2), 181-207.

Yin, R. K. (1994). Case Study Research: Design and Methods. Thousand Oaks, CA: Sage. Zeithaml, V. A., Berry, L. L. and Parasuraman, A. (1993). The Nature and Determination of Customer Expectation of Service. Journal of Academy of Marketing Science, 21(1), 1-12.

Zucker , R. (2002). More than a Name Change - Internal Branding at Pearl. SCM, 6(4), 24-27. 